\title{
Perspective
}

\section{The Azorean Biodiversity Portal: An internet database for regional biodiversity outreach}

\author{
PAULO A.V. BORGES ${ }^{1 \dagger}$, ROSALINA GABRIEL $^{1 \dagger}$, ANA M. ARROZ $^{1 \dagger}$, ANA COSTA $^{2}$, REGINA T. CUNHA $^{2}$, \\ LUÍS SILVA ${ }^{2}$, ENÉSIMA MENDONÇA ${ }^{1}$, ANTÓNIO M. F. MARTINS ${ }^{2}$, FRANCISCO REIS ${ }^{3}$ \& PEDRO CARDOSO PRA $^{1,4}$ \\ ${ }^{1}$ Azorean Biodiversity Group - CITAA, Departmento de Ciências Agrárias, Universidade dos Açores, 9701-851 Angra do Heroísmo, \\ Terceira, Açores, Portugal \\ ${ }^{2}$ CIBIO (Research Center in Biodiversity and Genetic Resources) - Pólo Açores, Departmento de Biologia, Universidade dos Açores, \\ 9501-801 Ponta Delgada, Portugal \\ ${ }^{3}$ Centro de Estudos do Clima, Meteorologia e Mudanças Globais (C_CMMG), Dep. Ciências Agrárias, Universidade dos Açores, \\ 9701-851 Angra do Heroísmo, Portugal \\ ${ }^{4}$ Smithsonian Institution, National Museum of Natural History, 10th \& Constitution NW, MRC 105, Room E-509, Washington, DC \\ 20560-0105, USA
}

(Received 15 September 2009; revised 31 May 2010; accepted 3 August 2010)

\begin{abstract}
There is a growing interest in academia to provide biodiversity data to both the scientific community and the public. We present an internet database of the terrestrial lichens, bryophytes, vascular plants, molluscs, arthropods, vertebrates and coastal invertebrates of the Azores archipelago (Portugal, North Atlantic): the Azorean Biodiversity Portal (ABP, http://www.azoresbioportal.angra.uac.pt/). This is a unique resource for fundamental research in systematics, biodiversity, education and conservation management. The ABP was based on a regional species database (ATLANTIS), comprised of grid-based spatial incidence information for $c .5000$ species. Most of the data rely on a comprehensive literature survey (dating back to the 19th century) as well as unpublished records from recent field surveys in the Azores. The ABP disseminates the ATLANTIS database to the public, allowing universal, unrestricted access to much of its data. Complementarily, the ABP includes additional information of interest to the general public (e.g. literature on Macaronesian biodiversity) together with images from collections and/or live specimens for many species. In this contribution we explain the implementation of a regional biodiversity database, its architecture, achievements and outcomes, strengths and limitations; we further include a number of suggestions in order to implement similar initiatives.
\end{abstract}

Keywords: Azores, biodiversity, database, science communication, species distribution, webpage

Human beings have the innate desire to catalogue, understand and spend time with other life forms. E. O. Wilson (1984)

Imagine an electronic page for each species of organism on Earth, available everywhere by single access on command. E. O. Wilson (1984) (http://www.eol.org/)

\section{Introduction}

The known biodiversity of the world currently includes approximately $1.8-1.9$ million described living species and

\footnotetext{
Correspondence to: Paulo A. V. Borges. E-mail: pborges@uac.pt ${ }^{\dagger}$ These authors contributed equally to this paper.

Contacts: Lichens and Bryophytes: Rosalina Gabriel, rgabriel@ uac.pt; Vascular Plants: Luís Silva, 1silva@uac.pt; Marine Invertebrates: Ana Costa, accosta@uac.pt; Mollusca: António Frias Martins, frias@uac.pt; Arthropoda: Paulo A. V. Borges, pborges@uac.pt; Vertebrata: Regina Cunha, rcunha@uac.pt.
}

an estimated 5-10 million undescribed species (May, 1988, 2009; Ødegaard, 2000). The available knowledge on biodiversity is still growing at increasing rates; consequently, new technologies of information outreach are necessary to allow the scientific community to manage all the data available at a given moment (Antezana et al., 2009). Additionally, the paradigm shift from the first Web generation applications and services to the Web 2.0, facilitated an interactive approach to information sharing and collaboration, which changed the user status from consumer to co-producer and helped to make scientific outreach a shared experience rather than an unilateral process.

There is a huge volume of information regarding biodiversity. However, there are very few data on many aspects of biodiversity due to: (i) the 'Linnaean' shortfall (Brown \& Lomolino, 1998), i.e. an incomplete taxonomic description of species-level diversity; (ii) the 'Wallacean' shortfall (Lomolino, 2004), i.e. incomplete knowledge of species' 
distributions; (iii) taxonomic knowledge being largely biased towards vertebrates and vascular plants (e.g. Gaston \& May, 1992; Rozzi et al., 2008), (iv) a geographical bias (Colwell \& Coddington, 1994; Lomolino, 2004; Hortal et al., 2007); and finally (v) the difficulty of accessing data in all fields other than molecular biology (Bisby, 2000; Parr \& Cummings, 2005). Because knowledge is also dependent on the number of people involved in its production, the few trained taxonomists available (Blackmore, 1996; Godfray, 2002; Leather, 2009; Boero, 2010) have a huge task ahead of them. Additionally, the rigidly defined role between providers and users of information, where there is almost no interaction between them in the production and processing of information, impoverishes and slows the scientific enterprise. Quality data on the presence and distribution of species gathered by many amateur naturalists are wasted unless this information is included in a recognized knowledge system. Moreover, interactions between the biodiversity stakeholders would foster new and stimulating questions and hypotheses, which would help advance the scientific enterprise in systematics, conservation and ecology (see e.g. Reed, 2008).

In spite of the above-mentioned limitations, there has been an acceleration of data production and a deep change in its outreach processes. Biodiversity informatics (Soberón $\&$ Peterson, 2004) and the emerging role of Semantic Web technology in the management of biological knowledge (Antezana et al., 2009) are at the centre of the new challenges and changes. These challenges mainly include the compilation and treatment (e.g. nomenclature updating, georeferencing) of label information from the millions of specimens deposited in thousands of public collections worldwide (Soberón et al., 1996; Edwards et al., 2000).

As the number of biodiversity informatics initiatives is large and rapidly growing, standards for sharing of information have been established. A major initiative in standardizing definitions is the Biodiversity Information Standards (TDWG; http://www.tdwg.org/). Many entities, both global and regional, are now following TDWG standards and providing data to a wider audience. In fact, many initiatives are gathering extensive amounts of taxonomic and distributional data for organisms. Currently, more than 600 projects are summarized on the Biodiversity Information Standards page (TDWG, http://www.tdwg.org/biodiv-projects/), which attests to the growing interest in sharing this type of information.

Portals are characterized by the trustworthiness of the scientific data available, the geographical area covered, the number and the amount of information regarding each taxon, and the volume of the resources offered. Additionally, researchers have been developing the interfaces of portals to achieve the highest possible user friendliness and interactivity. The Global Biodiversity Information Facility portal (GBIF; http://www.gbif.org), is certainly one of the most outstanding initiatives in terms of biodiversity information networks (see Edwards et al. 2000; Gilman et al., 2009). It aims to include all biological groups, in a global scope, and provides trustworthy taxonomic statuses and contains reliable sources of distribution. However, the resources available to each species is scarce. Comparable portals include Fauna Europaea (http://www.faunaeur.org), Flora Europaea (http://rbg-web2.rbge.org.uk/FE/fe.html) and the European Register of Marine Species (http://www.marbef.org/data/erms.php). Other portals aim to characterize each taxon in an intensive way by providing numerous resources to the general public or the scientific community. Some include a comparatively small geographical area, such as the UK Breeding Bird Survey (http://www.bto.org/bbs/index.htm), but others are global in scope, such as the Encyclopaedia of Life (http://www.eol.org/).

In this paper, we present the Azorean Biodiversity Portal (ABP, http://www.azoresbioportal.angra.uac.pt/), and compare its features to similar initiatives. We discuss its strengths and limitations considering the mainstream issues in the modern frames of scientific communication.

First, we describe the ATLANTIS database that is the basic source of data for the ABP and explain the development of the architectural process leading to the actual interface of this portal. The ABP plans to make available on the internet data for each species present in the Azores archipelago, including distribution maps and images, in an unbiased, exhaustive, high-quality and accessible format. The ABP attempts also to address the fundamental issues of data sharing and science communication in biodiversity for different stakeholders, such as taxonomists, ecologists and those involved in decision making in agriculture, forestry, nature conservation management, ecotourism and education, as well as the general public.

\section{The Azores in a Macaronesian context}

The Azorean Biodiversity Portal will share all the information available on the biodiversity of the Azores, one of the five Macaronesian archipelagos (Madeira, Salvage Islands, the Canary Islands and Cape Verde). Macaronesia is recognized as an important part of the Mediterranean hotspot of biodiversity (Myers et al., 2000); however, a comprehensive systematic revision of its biodiversity was still lacking at the end of the 20th century. Based on two European INTERREG IIIB projects (see Acknowledgements), an unprecedented collaboration of more than 200 taxonomists and other scientists resulted in accurate and comprehensive lists of terrestrial species in the Canary Islands (Izquierdo et al., 2001, 2004; Moro et al., 2003), Cape Verde (Arechavaleta et al., 2005), the Azores (Borges et al., 2005b, 2010) and Madeira-Selvagens (Borges et al., 2008). This unique collaboration was fundamental for creating the baseline taxonomic information for the ABP (see also Fig. 1), updating the taxonomic information, listing synonyms 


\begin{tabular}{|c|c|c|c|}
\hline & GATHERING DATA & FEEDING a DATABASE & SHARING DATA \\
\hline goal & $\begin{array}{l}\text { - to obtain all the records available } \\
\text { for each species }\end{array}$ & $\begin{array}{l}\text { - to evaluate and validate } \\
\text { taxonomic information and } \\
\text { the quality of the data }\end{array}$ & $\begin{array}{l}\text { - to provide: } \\
\text { - taxonomical information } \\
\text { - biodiversity accounts, such as } \\
\text { richness or endemism } \\
\text { - distribution maps } \\
\text { - links and news } \\
\text { - detailed identification of taxa } \\
\text { upon requestby users }\end{array}$ \\
\hline source & \begin{tabular}{c|l} 
- published & $\begin{array}{l}\text { - papers } \\
\text { - books }\end{array}$ \\
- unpublished & $\begin{array}{l}\text { - Field reports } \\
\text { - Project reports } \\
\text { - Specialist } \\
\text { documents } \\
\text { - Herbaria and } \\
\text { animal collections }\end{array}$
\end{tabular} & $\begin{array}{l}\text { - documents } \\
\text { - pictures to illustrate each } \\
\text { species } \\
\text { - Nature photographs } \\
\text { - Syncroscopy images } \\
\text { - Microscopy photos }\end{array}$ & $\begin{array}{l}\text { - team identification and contacts } \\
\text { - team publications } \\
\text { - images } \\
\text { - free pdf documents }\end{array}$ \\
\hline location & -Azorean islands & $\begin{array}{l}\text { - transforming alpha-numeric } \\
\text { information into a georeferenced } \\
\text { grid map }(500 \times 500 \mathrm{~m})\end{array}$ & $\begin{array}{l}\text { - provide detailed distribution } \\
\text { data (tabulated or GIS format) } \\
\text { upon request by users }\end{array}$ \\
\hline time & - through historical time & $\begin{array}{l}\text { - register or estimate the } \\
\text { historical year of the } \\
\text { observations }\end{array}$ & $\begin{array}{l}\text { - detailed temporal data upon } \\
\text { request by users }\end{array}$ \\
\hline & DATA OVERLAPPING & $\begin{array}{l}\text { ATLANTIS } \\
\text { DATABASE }\end{array}$ & $\begin{array}{c}\text { AZOREAN } \\
\text { BIODIVERSITY PORTAL }\end{array}$ \\
\hline
\end{tabular}

Fig. 1. Flow chart indicating the processes, products and outcomes in relation to the Azorean Biodiversity Portal.

of the species, and quantifying the total number of described species in Macaronesia. Presently, the number of unique endemic species and subspecies of terrestrial organisms (lichens, plants and animals) is estimated to be approximately 6051 in this region: 420 for the Azores (Borges et al., 2005b, 2009, 2010), 1419 for Madeira (Borges et al., 2008), 3672 for the Canary Islands (Izquierdo et al., 2004) and 540 for the Cape Verde Islands (Arechavaleta et al., 2005).

\section{The Azorean Biodiversity Portal architecture}

The Azorean Biodiversity Portal was inspired by a number of similar initiatives (Table 1). It was intended to provide not only taxonomic and incidence data, but also images of most species. Before sharing the information in the ABP, it was necessary to gather and interpret a considerable amount of data, as summarized in Fig. 1. Three stages underlie this operation.

\section{Gathering data}

First, there was a data-gathering stage, which comprised both an exhaustive literature review of taxonomic and distributional data, but also data from museum collections (e.g. the University of Azores' entomological and bryological collections). In fact, data from museum collections are one of the most valuable resources for biodiversity conservation (Soberón et al., 2000) and research in general (Suarez \& Tsutsui, 2004).

The documents acquired included not only published material but also unpublished BAs, MSc and $\mathrm{PhD}$ theses, expert field reports and data from herbaria and animal collections in museums or universities. Data were from the 19th century through to the present day.

\section{Feeding a database}

To reach a more general audience, the gathered information was stored in an MS SQL database, using a software tool, Atlantis Tierra 2.0, created by the Canaries Conservation Bureau. The software was written in Visual Basic and uses the SQL language to develop queries, and it can easily interface with GIS software. Atlantis Tierra 2.0 was inspired by the 'Worldmap Distribution Analysis Software' (http://www.nhm.ac.uk/research-curation/research/projects/ worldmap/worldmap/demo2.htm) (see also Williams, 1999) but has several innovative features. Within the ATLANTIS database, it is possible to store detailed information for each species, including their taxonomy, georeferenced distribution data, species description, 
P. A. V. Borges et al.

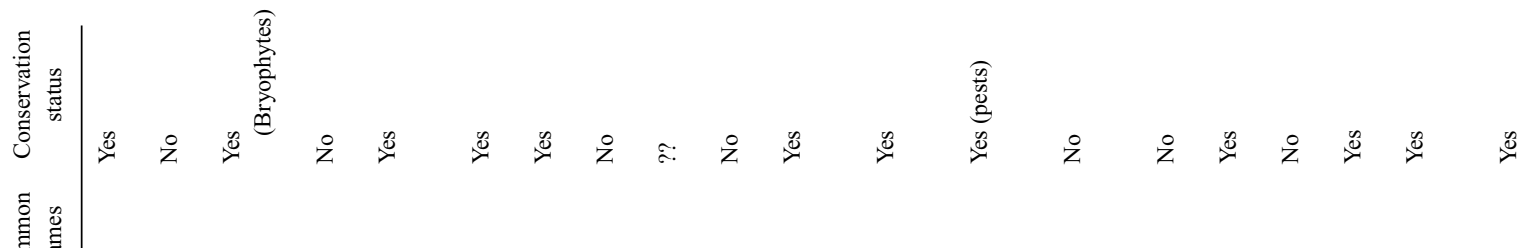

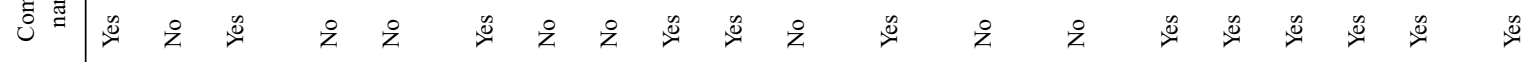

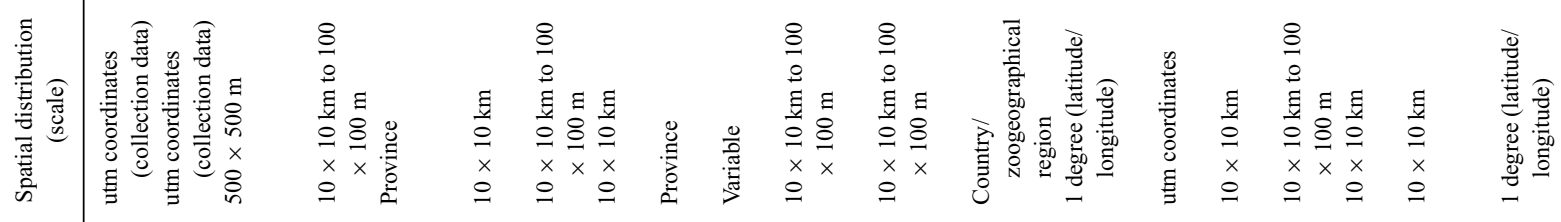

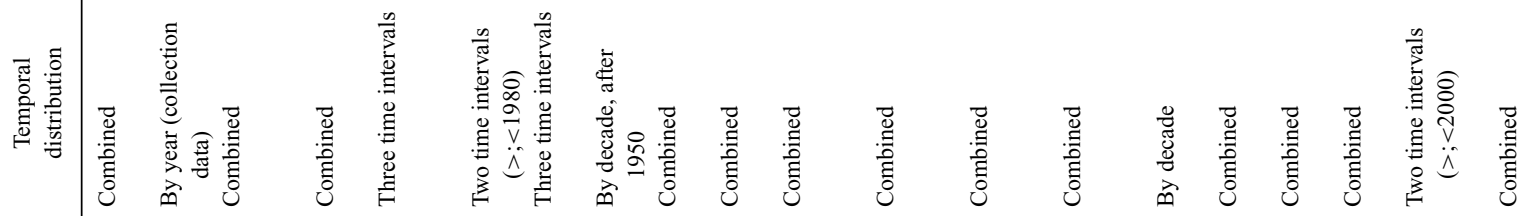

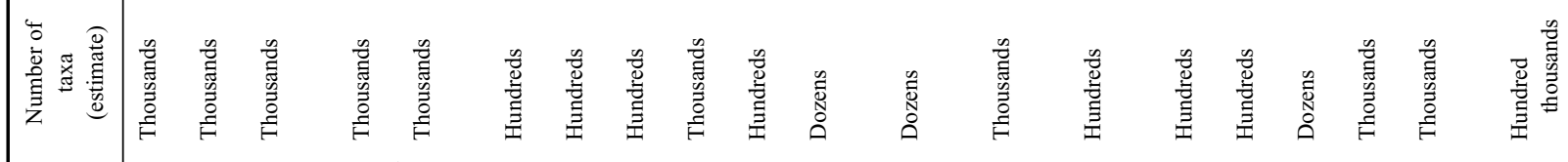

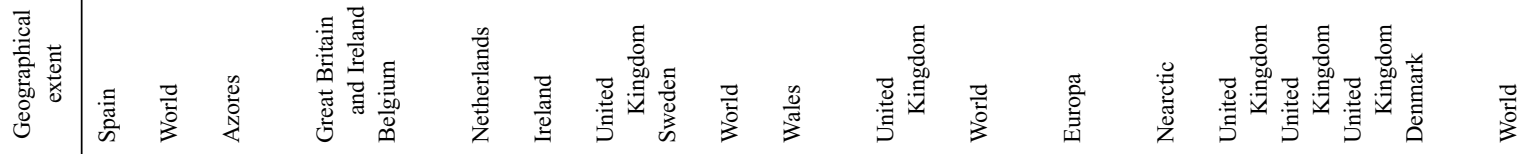

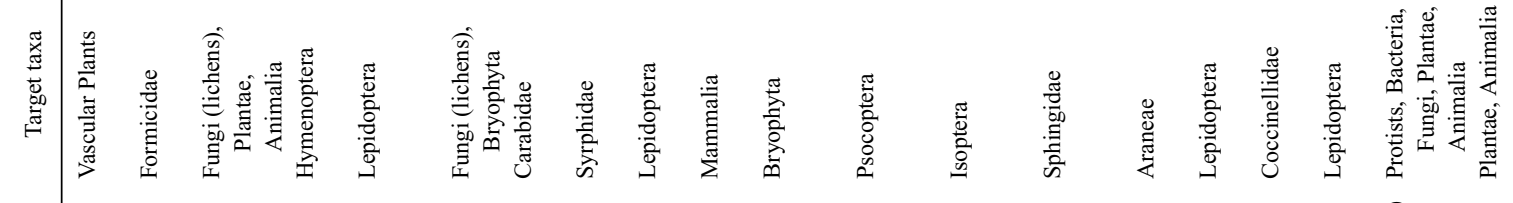

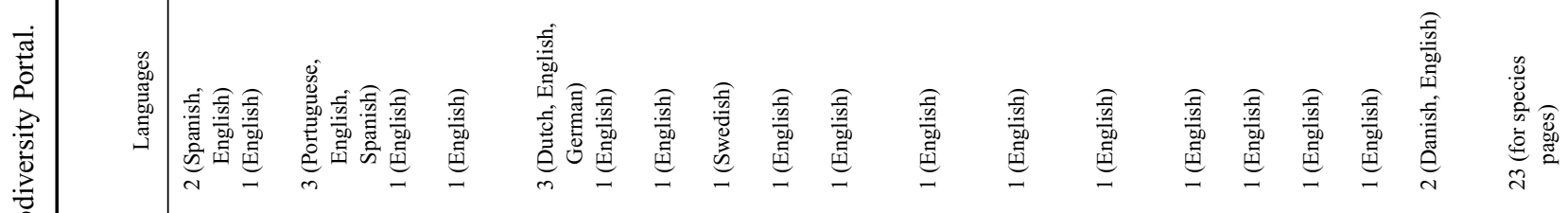

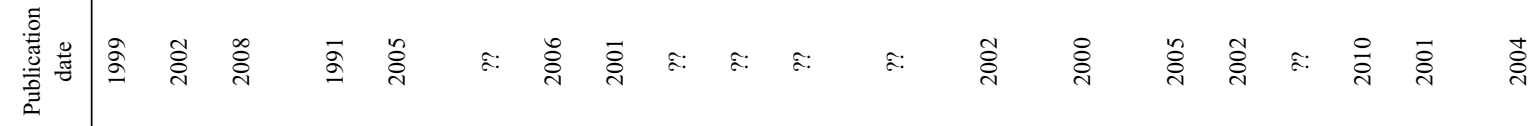

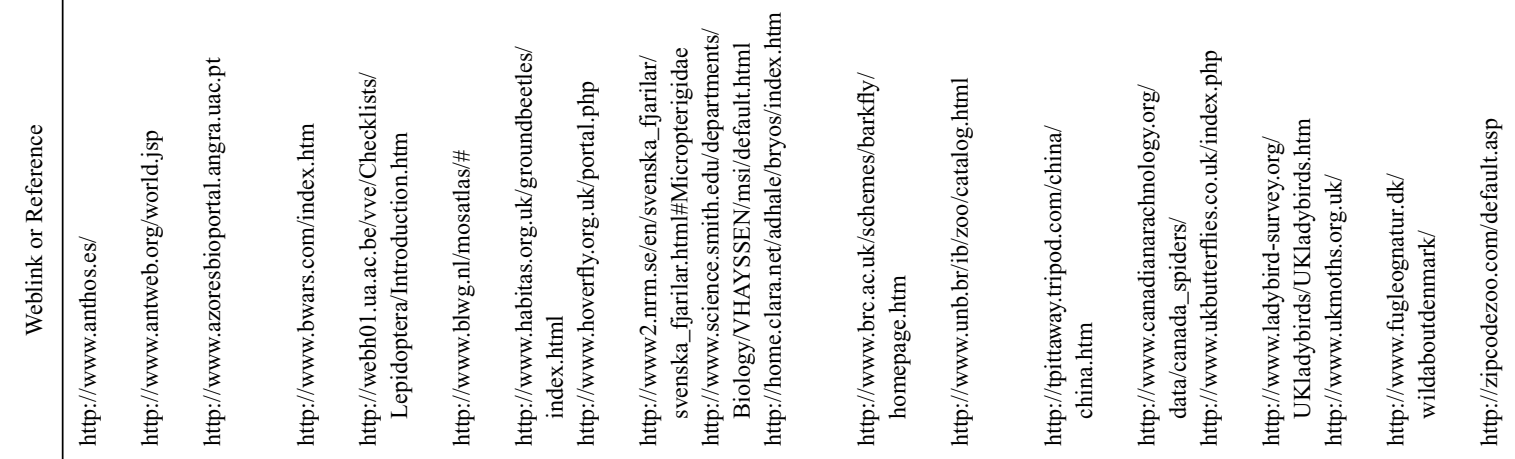

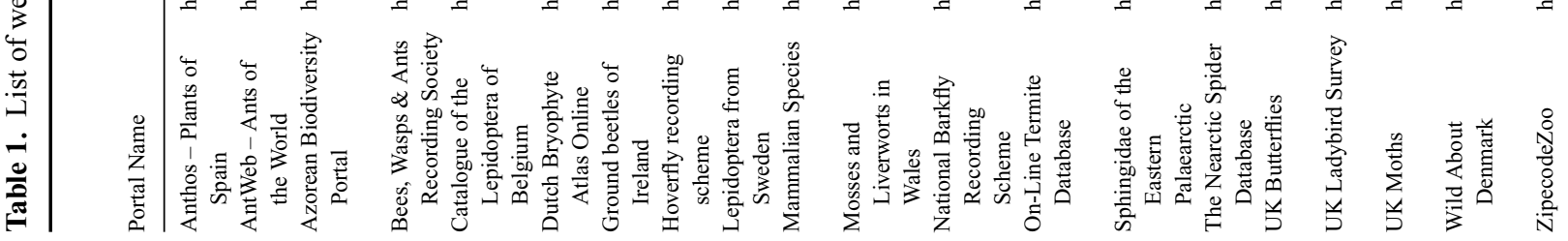




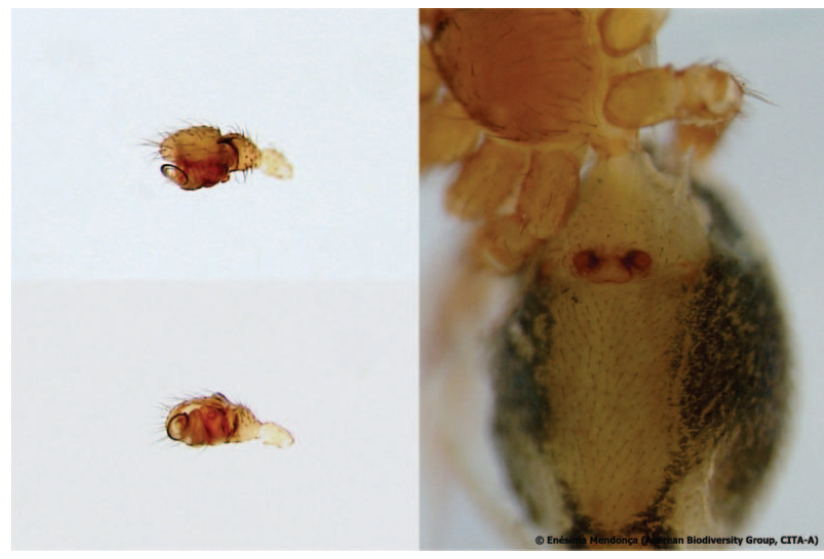

Fig. 2. The endemic Azorean spider Walckenaeria grandis (Araneae, Linyphiidae). Details of both male left palp (lateral and ventral view) and female epigyne.

photographs, ecology, conservation status and colonization status (endemic, native, exotic) (Borges, 2005; Zurita \& Arechavaleta, 2003). Additionally, Atlantis Tierra 2.0 has a conservation management analysis tool that allows the calculation of species richness, rarity or complementarity (displays the minimum number of cells required to ensure that each species in the dataset is represented at least once) in all $500 \times 500 \mathrm{~m}$ cells of a particular island or in any special area of one island.

Data input is complex and requires interpretation and validation by experts at two levels: (i) taxonomic validation, where synonyms are traced and accepted species names are updated (see Borges et al., 2005b, 2010), and (ii) occurrence data evaluation, where each record is classified as secure or doubtful according to the reliability of the source and where the precision of the distribution is qualified ( $1=$ very precise locations, usually point UTM data, $2=$ localities not exceeding $25 \mathrm{~km}^{2}, 3=$ imprecise localities, and $4=$ island occurrence [generally old publications]). All records are linked to the year of observation or collection of the species.

Additionally, photographs were obtained for each species. Most of the photographs represent the species in nature or in collections, while others represent details relevant for their identification (see Fig. 2).

All data digitization was performed during 5 years (2004-2008) by five specially trained technicians (i.e. 300 hours per person/month) supported by research grants from the EU INTERREG IIIB and the Azorean Government (Director of the Environment).

\section{Sharing data}

Information contained in the ATLANTIS database is now being made universally available through the Azorean Biodiversity Portal (ABP, http://www.azoresbioportal.angra. uac.pt/), which presents a wealth of resources not only for

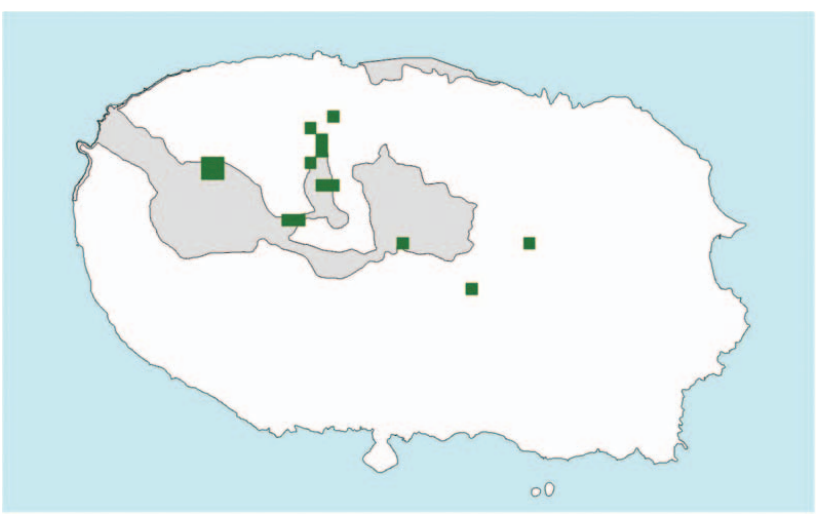

Fig. 3. Example of a detailed distribution of a species on a 500 $\times 500 \mathrm{~m}$ grid, based on a query generated by the ATLANTIS Tierra 2.0 software. The figure shows the distribution of the endemic ground-beetle Trechus terceiranus (Coleoptera, Carabidae) on Terceira island, with a layer indicating the NATURA 2000 protected area.

each Azorean species, but also for Macaronesian biodiversity. This portal is available in Portuguese, Spanish and English.

For each species, it is possible to access basic taxonomic information, common names, images (when available) and two kinds of distribution maps. One of the distribution maps illustrates the archipelago with an indication of island occurrence, and the other map illustrates detailed distribution information for each island using only data with distribution precision 1 and 2 from the ATLANTIS database (see Fig. 3).

Apart from the ATLANTIS database information, it is also possible to access a large and growing number of resources (e.g. free online PDFs of publications, news, web links). In this way, the ABP is creating a repository of all the biodiversity literature on Macaronesia. Presently, the ABP includes the following (Fig. 1): (i) general news related to the Azorean and Macaronesian biodiversity; (ii) a broad thematic list of links categorized by different fields of knowledge (e.g. evolution, ecology, biogeography, conservation, etc.) or origin (scientific journals, nature photography sites, etc.); (iii) downloadable publications on the Azores and Macaronesian biodiversity, including recent books such as Borges et al. (2005b, 2008, 2010), Martín et al. (2008), Silva et al. (2008), Borges \& Gabriel (2009), Silva \& Gabriel (2009), Martins (2009), and older works, including taxonomic publications of reference. Additionally, the ABP contains documents specifically created for the portal that may be useful to the educators (e.g. lists and richness maps of endemics and exotic taxa by island, identification guides for spiders or birds). However, the pictures are possibly the single most useful educational resource on the html species' pages. There are currently 6086 photographs available covering 2061 of the 4467 listed terrestrial taxa of the Azores, and the ultimate goal is to illustrate every 


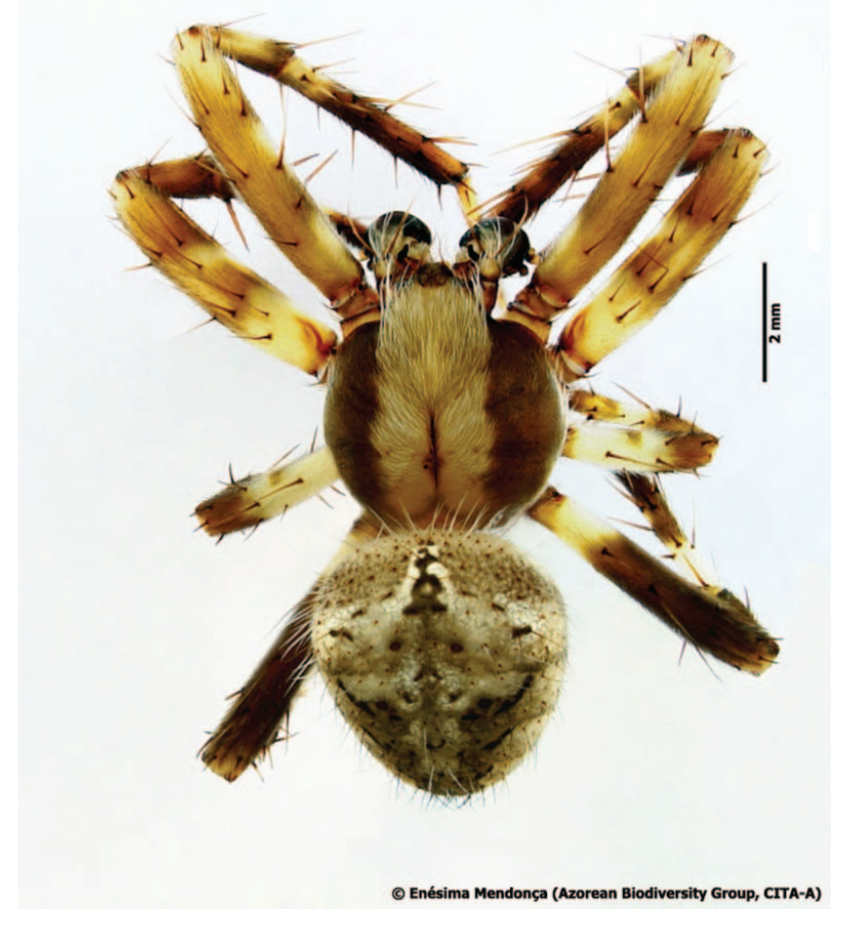

Fig. 4. Agalenatea redii (Araneae, Araneidae) male habitus. A perfectly focused 3-D image using the Syncroscopy AutoMontage system.

species, including not only their habitat in the wild, but also details of their diagnostic features. For some species in selected groups, such as spiders and beetles, a collection of enlarged depth-of-field images of collection specimens is being made using the Syncroscopy AutoMontage system (see http://www.synoptics.co.uk) (e.g. Fig. 4), while other groups, such as lichens and bryophytes, include microscopic images of spores, leaves and thalli. This approach is not a substitute for keys and other identification guides, but it provides a faster way to diagnose the characters of a genus or family. Fortunately, the ABP is also attracting the cooperation of many nature photographers, who contribute their images and recognize that this platform is an excellent opportunity to promote their work and highlight the species occurring in the Azores. These images make a huge difference in gaining and sustaining the interest of the general public, and accordingly, the pages lacking pictures are comparatively less visited.

The website was created entirely using open source technology. The dynamic web pages were developed in Php, Javascript and the data stored in a MySQL database. The website administration is performed by accessing a password-protected administration section. Webserver application is the Apache that is running on a Linux platform.

The maintenance of the ABP requires the frequent updating of the ATLANTIS database for new species and new distribution data, which are updated monthly to the portal by the webmaster. New resources, such as new links and free documents are added continuously by the coordinator. These activities required two part-time positions in 2009, which have been funded by two research centres at the University of the Azores (CITA-A and CIBIO-Azores). In 2010-2013, one position will be financed full-time by the Portuguese Science Foundation (FCT) under a CITA-A project.

The number of visits to the site is increasing steadily, with an average of 2190 visits per day in April 2010 and a total of 493459 visits in the year 2009. The number of downloads of the ten most accessed PDFs ranged from 565 to 2684, in April 2010, with the lists of the Macaronesian fauna and flora (Izquierdo et al., 2004; Arechavaleta et al., 2005; Borges et al., 2005b, 2008) being among the most accessed documents.

The ABP generates a positive flow of new information (e.g. distributions of species, images, PDFs) sent by the public and colleagues. It also provides an outlet for specific requests concerning Azorean taxa, and promotes collaborative initiatives (see Fig. 1), increasing knowledge on Azorean biodiversity.

\section{Achievements and outcomes}

The creation and maintenance of a web application such as the Azorean Biodiversity Portal (ABP) may be very useful for research, management, education and communication. Some of the outcomes already achieved by the ABP are listed below.

\section{Science}

One of the most striking benefits of the dissemination of the information compiled in the ATLANTIS database is to provide resources for colleagues in academia. These resources can be used to test a number of biogeographic and macroecological hypotheses on island systems. Recent examples of published collaborations include studies on the patterns of endemic arthropod species richness (Borges \& Wunderlich, 2008; Borges \& Hortal, 2009; Cardoso et al., 2010; Santos et al., 2010, Triantis et al., 2010), the spread of invasive species (Hortal et al., 2010), the application of presence/absence models as surrogates of arthropod abundance (Jiménez-Valverde et al., 2009) and the use of data for species distribution modelling (Hortal et al., 2005; Jiménez-Valverde et al., 2008).

\section{Management}

By providing unrestricted, detailed information on the distribution of species, the ABP contributes to conservation efforts in the Azores. Government managers frequently consult the team to obtain data on individual species distributions or maps of species richness, and such information has been used to reshape the boundaries of protected areas of the region, both terrestrial and coastal. Moreover, distribution data are useful to different stakeholders. Free access encourages citizen participation, and may facilitate their involvement in planning of new infrastructures affecting their 
residence areas. Good examples of the use of distribution data for management purposes include a recent book that prioritized the 100 species most important for conservation (Martín et al., 2008) and another book identified the 100 invasive species of greatest concern for Macaronesia (Silva et al., 2008). In both cases detailed information on the distribution of rare or invasive species was necessary and historical and current distribution data stored in ATLANTIS database was essential for the species evaluation and ranking process. Species conservation is never an easy task and requires the joint efforts of the scientific community, policy-makers, environmentalists and other stakeholders; however, we suggest that these initiatives provide a solid base for long-term monitoring in the region, as they readily inform different stakeholders about rare and invasive species, helping to define concrete conservation measures and enhance protective attitudes.

\section{Education outreach and communication}

One of the main purposes of the ABP is to enhance public knowledge and appreciation of the Azorean biodiversity. The ABP provides a wide range of resources that are used to promote students' autonomy on the elaboration of herbarium projects, by improving their species identification skills and the understanding of higher-rank taxonomy, allowing them to compare current published distributions with their observations; after validation, their records are used to feed the database, promoting collaborative work among scientists, teachers and students. Besides, the ABP has also been used as an important tool in the development and evaluation of educational projects, mainly on endemic, native and introduced species, supporting in-service programmes for teachers (e.g. FLAD, 2010). Furthermore, since the implementation of the ABP, there was an increase in the communication among local people and the team, and as a result more data on the distribution of species is being provided by non-experts.

\section{Strengths and limitations}

The three most important data issues to users are: (i) data quality, (ii) data completeness and (iii) whether data are upto-date. In our view, the main strengths of the Azorean Biodiversity Portal (ABP) and its database ATLANTIS compared with other identical initiatives (see Table 1) include the following:

1. A wide taxonomic scope. Most databases are either limited in taxonomic scope and are unbiased, or they have a large scope but are biased towards some organisms (usually vertebrates or vascular plants). In the ABP, while the scope is wide, it is not, however, completely lacking groups such as Fungi and Nematoda.

The information provided is exhaustive. We attempted to include all available data for all species. We had the explicit purpose of not limiting the avail- able data to a subset of what was published or housed in collections.

2. The quality control of the data. As the portal includes regional experts on each taxonomic group, all data were strictly checked for taxonomic correctness (e.g. misidentifications, synonymies) and geographical inaccuracies and errors were corrected (e.g. spelling errors, wrong labels).

3. Accessible format of the information for a general audience. Overcomplicated table formats or other common impediments to public understanding of the data were avoided.

4. Availability of high quality images for most species. This includes both 3D microscopic images (see Figs 2 and 4) and nature photography.

5. A number of additional resources. Besides the html files online with the taxonomic information of the species and distribution maps of the islands, there is a diverse collection of literature on Azorean and Macaronesian biodiversity and ecology (many of which are open source) and a large and broad thematic list of links.

6. Possibility of public participation. Anyone interested in contributing information to the database may do so, either with photographs, records of species for different locations, documents to be shared, etc., where these contributions are addressed to the coordinators of each taxonomic group.

The second, third and fourth points are arguably the main weaknesses in GBIF, which is the main biodiversity database initiative at a worldwide level. By focusing on the regional level we could tackle each of these shortcomings (see Guralnick et al., 2007) and also provide a useful, comprehensive system to the Azores archipelago.

Despite these advances, some limitations should also be recognized:

(i) The current version of the portal does not follow any of the available database sharing standards (e.g. TDWG). This was due to the structure of the ATLANTIS database as implemented by the Environment Bureau of the Government of Canary Islands, which was built for a very specific purpose, namely the support of local conservation management in the Canary Islands (see Zurita \& Arechavaleta, 2003). Its use in the internet and other regions besides the Canary Islands was not initially planned, and its shortcomings are now evident.

(ii) Presently, the database is not connected to GBIF. Besides the original database format as explained above, this disconnection is primarily due to the absence of an active national node for GBIF in Portugal. Actually, most of the data coming from Portuguese institutions and researchers are being fed to that database through the Spanish node, a temporary but long-lasting situation. 


\section{Box 1. How to create a regional online biodiversity portal step by step.}

\section{Team}

(a) Promote a multidisciplinary network of specialists on: (i) the taxonomy of the target groups, (ii) database management, (iii) web design and (iv) knowledge organization systems (KOS).

(b) Manage the different kinds of expertise available on the team, based on the specific needs of each project phase.

Note: It is essential to select or train technicians in taxonomy and GIS and promote collaboration with image providers (professionals and amateurs), ethnologists and historians (for obtaining local species names).

\section{Data sources}

(a) Plan a comprehensive strategy of information gathering, selecting an array of data sources, including all published literature and reports coming from mapping projects, faunistic monitoring, animal collections, herbaria, letters, travel reports and journals and other private unpublished records. If not available, an important step is the creation of a checklist of all the species occurring in the target region and an exhaustive list of synonyms. This will allow an accurate interpretation of the old historical literature.

(b) Obtain all the possible environmental information for the target region (e.g. digital elevation maps, spatial location of roads, pathways and water courses, names of localities) to be added as layers in a GIS environment. This will allow a correct interpretation of the distribution of species.

(c) Guarantee that all the information is adequately stored and available for consultation.

\section{Database}

(a) Design a database for biodiversity data storing and management. So far we have been successfully using SQL. If possible, we suggest following the TWDG standards, such as Darwin Core.

(b) Choose software (e.g. Atlantis Tierra 2.0 or internet platforms) for an easy interface with the database allowing its proper feeding.

(c) Determine optimal solutions to minimize errors in feeding the database. In addition, the technicians should work in close connection with the taxonomic coordinators allowing an easy interpretation of the taxonomic literature.

Note: The software may use the SQL language to develop interrogation queries and should have an easy interface with all Geographic Information System (GIS) software. Ideally the feeding of data should be performed online facilitating the participation of experts of different regions or countries (see also Frazier et al., 2008 for a detailed appraisal on how initiate a digitization project).

\section{Biodiversity portal}

(a) Define the aims of the portal and the services to be provided.

(b) Together with a web designer, create its architecture.

Note: It is important to guarantee a pleasant and informative experience to the user. Therefore, all efforts should be taken to allow an easy access to the information, providing a clear, structured and intuitive navigation.

(c) Promote the sharing of information among users and data providers (e.g. allowing access to the original database; receiving and making available information collected by users such as pictures, new records of species or locations).

(d) Ensure the updating of all the available information and create new resources, as they are needed/requested, assuring that all the novelties are easy to see and access.

(e) Create a regulation system that allows the validation and monitoring of the comprehension, functionality and satisfaction of the users in all stages of the process, conjugating quantitative (e.g. number of visits, number of downloads) and qualitative (e.g. feedback on-line questionnaires, e-mail messages) data.

\section{Funding and long-term management}

(a) Last but not least, guarantee the interest of funding agencies, for the short- and long-term maintenance of both the database and the portal.

(b) If possible, maintain partnerships with conservation and education stakeholders that endorse the use of the portal as a resource to promote the biodiversity of the region. 
(iii) Currently available maps are pooled temporal maps including both old historical records and current recent data. In spite of the limitations of such maps, the original data may be consulted, upon request, to the ATLANTIS database, presently located at the University of Azores and the Regional Government of the Azores. If a large quantity of data is requested for a specific purpose, we try to collaborate to ensure proper data use.

(iv) Despite our best efforts, the quality of detailed spatial data is not uniform for all the taxa and should be carefully scrutinized before it is used for ecological modelling (see e.g. Hortal et al., 2007; Soberón et al., 2007).

(v) A shortcoming common to most databases is the absence of good quality information on the distribution of common species (e.g. urban species, pests of stored products, etc.) due to the absence of records in the literature. Accordingly, native species tend to be better surveyed in the Azores due to the recent investments in their study (e.g. arthropods: Borges et al., 2005a; vascular plants: Dias, 1996; Schaefer, 2003; Silva \& Smith, 2006; bryophytes: Gabriel \& Bates, 2005). Nevertheless, the distributional patterns of the surveyed species provide important information for optimizing sampling and identifying information gaps in certain territorial areas.

\section{Future developments}

The success of regional initiatives like the Azorean Biodiversity Portal has created effective ways to communicate biodiversity knowledge not only to teachers and researchers in schools and universities, but also to members of NGOs and other stakeholders. Therefore, future development of the ATLANTIS database and the associated ABP will aim to increase its usefulness for planning and conservation and to support stakeholders, politicians and managers with scientific information. Optimization of this information is essential. This includes a continuous update of data and an investment in research on taxonomic groups yet to be included in the database (e.g. fungi, diatoms, many marine invertebrates and vertebrates) and in the territories where information on native speces is still missing. Moreover, integrating information from other ongoing biodiversity research projects in the region is highly desirable, as it enhances the social awareness of current scientific efforts. In the near future and with the financial support of the Azorean government, we hope to include the Azorean coastal fish in the ATLANTIS database.

Future ABP developments should include the ability to query and generate maps of species richness in order to identify hotspots of richness, distribution patterns of exotic species, gaps in species inventories, and so forth. We are working to provide these features in the future, since they are already available in the original ATLANTIS database. As there are few experts and non-experts involved in recording new localities for species, we hope that the ABP may inspire new efforts to accomplish this important task.

While we cannot predict all the communication tools that will be developed for the ABP in the near future, we anticipate that the following types of activities will soon be available within the framework of the recently created UNESCO Regional Centre of Expertise Network RCE-Azores (http://rceazores.ning.com) for which the ABP is a partner and mean of communication: (i) popularizing the conservation of endemic species to the general population through new subpages and photography contests; (ii) adding lists of the references used for the compilation of distribution data for each species.

\section{Conclusions}

For most countries and taxa, it is difficult to obtain an adequate overview of species-level biodiversity, even for well-studied taxonomic groups (but see Table 1 for a non-comprehensive set of similar initiatives). Identifying species correctly and having a basic knowledge of their distributions, abundances and colonization status (e.g. endemic, native, exotic) or conservation status (e.g. rare, vulnerable, invasive) is a fundamental requirement for sound science in conservation biology and for its implementation in public policy (see Box 1). Following the strategy of recent initiatives like the European Distributed Institute of Taxonomy (EDIT; http://www.e-taxonomy.eu), we intend to improve the communication between current data owners and a new generation of taxonomists and the general public.

The wealth of unique species, many of them under threat (Martín et al., 2008, 2010) and the information gathered in the process of publishing species checklists led to the conceptualization of a project that would highlight the biological importance of taxa and improve accessibility to information on the systematics and distribution of species.

Some evidence indicates that a larger segment of human society is detached from nature than ever before (Mehtälä \& Vuorisalo, 2005). Consequently, communication to the public and their participation is of great importance to biodiversity conservation. The rapid advancement of fields, such as molecular biology and genomics, is in large part due to a strategy directed at data sharing (see e.g. Parr \& Cummings, 2005; Valentini et al., 2009). In the fields of taxonomy, conservation biology and ecology, this kind of practice is still lacking. However, the IUCN has launched the Conservation Commons Initiative (http://conservationcommons.org/), a step forward in promoting the sharing of biodiversity data to facilitate the conservation and sustainable use of biodiversity. 
Species lists at the regional level (at least the national and sub-national scales) are lacking (but see good examples in Table 1). The Azorean Biodiversity Portal resulted from the synergy and collaboration of taxonomists, showing that such collaboration is possible. We believe that the ABP and its baseline-database ATLANTIS will facilitate (i) the selection of biodiversity hotspots within the Azores and (ii) the identification of sets of territorial units that would maximize the number and diversity of effectively protected species. Facilitating the use of biodiversity data may contribute to successful conservation programmes.

The Azorean Biodiversity Portal allows the general public to grasp biodiversity in an intuitive, simple and easy way, and it indirectly communicates the value and uniqueness of each species through carefully chosen photographs. It also promotes participation by the public and other scientists in the completion of the ATLANTIS database, where people can send records and pictures to group coordinators to be considered for addition to the database after proper validation. Moreover, the raw data are also available to any scientist who contacts the group coordinators (see footnote for e-mail addresses).

In conclusion, by being a regional initiative, we believe that the Azorean Biodiversity Portal can provide better services, that are more suited to local users and their needs because it is easier to make direct contact with the relevant stakeholders. In addition, we emphasize the positive effect that the ABP can have on the Azorean community, by fostering an appreciation of the Azorean biodiversity within the community.

\section{Acknowledgements}

We are grateful to José Luis Martin for his vision in leading the ATLANTIS database creation. We thank the Editor, Elliot Shubert, and two anonymous referees for helpful comments. The generation of the 'The Azorean Biodiversity Portal' was one of the objectives of the ATLANTICO and BIONATURA Interreg IIIB projects, with the general coordination of Dirección General del Medio Natural del Gobierno de Canarias and Azorean coordination of ARENA (Azores) and Direcção Regional do Ambiente (Azores). The website is currently being funded by CITA-A (University of Azores) and 'Direç̧ão Regional do Ambiente e do Mar' (Azores Government). PAVB is currently being funded by the FCT Projects (PTDC/BIABEC/100182/2008 and PTDC/BIA-BEC/104571/2008).

\section{References}

AnteZana, E., Kuiper, M. \& Mironov, V. 2009. Biological knowledge management: the emerging role of the Semantic Web technologies. Briefings in Bioinformatics 10, 392-407.

Arechavaleta, M., Zurita, N., Marrero, M.C. \& Martín, J.L. 2005. Lista preliminar de especies silvestres de Cabo Verde (hongos, plantas y animales terrestres). Consejería de Medio Ambiente e Ordenación Territorial, Gobierno de Canarias, Santa Cruz de Tenerife.

BISBY, F.A. 2000. The quiet revolution: biodiversity informatics and the internet. Science 289, 2309-2312.

BLACKMORE, S. 1996. Knowing the Earth's biodiversity: challenges for the infrastructure of systematic biology. Science 274, 63-64.

Boero, F. 2010. The study of species in the era of biodiversity: a tale of stupidity. Diversity 2, 115-126.

Borges, P.A.V. 2005. Introduction. In: Borges, P.A.V., CunHA, R., Gabriel, R., Martins, A.M.F., Silva, L. \& Vieira, V., Eds., $A$ List of the Terrestrial Fauna (Mollusca and Arthropoda) and Flora (Bryophyta, Pteridophyta and Spermatophyta) from the Azores. Direcção Regional de Ambiente and Universidade dos Açores, Horta, Angra do Heroísmo and Ponta Delgada, pp. 11-20.

Borges, P.A.V., Abreu, C., Aguiar, A.M.F., Carvalho, P., Jardim, R., Melo, I., Oliveira, P., SÉrgio, C., Serrano, A.R.M. \& VIEIRA, P., Eds., 2008. A List of the Terrestrial Fungi, Flora and Fauna of Madeira and Selvagens Archipelagos. Direcção Regional do Ambiente da Madeira and Universidade dos Açores, Funchal and Angra do Heroísmo.

Borges, P.A.V., Aguiar, C., Amaral, J., Amorim, I.R., André, G., Arraiol, A., Baz, A., Dinis, F., Enghoff, H., Gaspar, C., Ilharco, F., Mahnert, V., Melo, C., Pereira, F., Quartau, J.A., Ribeiro, S., Ribes, J., Serrano, A.R.M., Sousa, A.B., Strassen, R.Z., Vieira, L., Vieira, V., Vitorino, A. \& WundERLICH, J. 2005a. Ranking protected areas in the Azores using standardized sampling of soil epigean arthropods. Biodiversity and Conservation 14, 2029-2060.

Borges, P.A.V., Amorim, I.R., Cunha, R., Gabriel, R., Martins, A. F., Silva, L., Costa, A. \& Vieira, V. 2009. Azores. In: Gillespie, R. \& Clague, D., Eds., Encyclopedia of Islands. University of California Press, Berkeley, CA, pp. 70-75.

Borges, P.A.V., Costa, A., Cunha, R., Gabriel, R., Gonçalves, V., Martins, A.F., Melo, I., Parente, M., Raposeiro, P., RoDrigues, P., Santos, R.S., Silva, L., Vieira, P. \& Vieira, V., Eds., 2010. A List of the Terrestrial and Marine Biota from the Azores. Princípia, Oeiras.

Borges, P.A.V., Cunha, R., Gabriel, R., Martins, A.F., Silva, L. \& VIEIRA, V., Eds., 2005b. A List of the Terrestrial Fauna (Mollusca and Arthropoda) and Flora (Bryophyta, Peridophyta and Spermatophyta) from the Azores. Direcção Regional do Ambiente and Universidade dos Açores, Horta, Angra do Heroísmo and Ponta Delgada.

Borges, P.A.V. \& Gabriel, R. 2009. Predicting Extinctions on Oceanic Islands: Arthropods and Bryophytes. Universidade dos Açores. Angra do Heroísmo. (http://www. azoresbioportal.angra.uac.pt/files/publicacoes_Brochura\% 20BIODIVERSIDADE\%20AORES\%20vFINAL.pdf, accessed August 5, 2010).

Borges, P.A.V. \& Hortal, J. 2009. Time, area and isolation: factors driving the diversification of Azorean arthropods. Journal of Biogeography 36, 178-191.

Borges, P.A.V. \& Wunderlich, J. 2008. Spider biodiversity patterns and their conservation in the Azorean archipelago, with description of new taxa. Systematics and Biodiversity 6, 249-282.

Brown, J.H. \& Lomolino, M.V. 1998. Biogeography. Second edition. Sinauer Associates, Sunderland, MA.

Cardoso, P., Arnedo, M.A., Triantis, K.A. \& Borges, P.A.V. 2010. Drivers of diversity in Macaronesian spiders and the role of species extinctions. Journal of Biogeography 37, 1034-1046. 
Colwell, R.K. \& Coddington, J.A. 1994. Estimating terrestrial biodiversity through extrapolation. Philosophical Transactions of the Royal Society of London B 345, 101118.

DiAs, E. 1996. Vegetação natural dos Açores: ecologia e sintaxonomia das florestas naturais. Ph.D. Thesis, Universidade dos Açores, Angra do Heroísmo.

EDWARDS, J.L., LANE, M.A. \& NIELSEN, E.S. 2000. Interoperability of biodiversity databases: biodiversity information on every desktop. Science 289, 2312-2314.

FLAD (2010). Cidadania e sustentabilidades para o séc. XXI. Caminhos para uma comunidade sustentável nos Açores. Proj. 3.GAV 339/2008

FraZIER, C.K., WALL, J. \& Grant, S. 2008. Initiating a Natural History Collection Digitisation Project, version 1.0. Global Biodiversity Information Facility, Copenhagen.

GABRIEL, R. \& BATES, J.W. 2005. Bryophyte community composition and habitat specificity in the natural forests of Terceira, Azores. Plant Ecology 177, 125-144.

Gaston, K.J. \& MAY, R.M. 1992. The taxonomy of taxonomists. Nature 356, 281-282.

Gilman, E., King, N., Peterson, T., Chavan, V., \& Hahn, A. 2009. Building the Biodiversity Data Commons - The Global Biodiversity Information Facility. In MAURER, L., Ed., ICT for Agriculture and Biodiversity Conservation. ICT Ensure, Graz University of Technology, Graz, pp. 79-102.

GODFRAY, H.C.J. 2002. How might more systematics be funded? Antenna, 26, 11-17.

GuRALnick, R.P., HiLl, A.W., \& Lane, M. 2007. Towards a collaborative, global infrastructure for biodiversity assessment. Ecology Letters 10, 663-672.

Hortal, J., Borges, P.A.V., Dinis, F., Jiménez-Valverde, A., Chefaoui, R.M., Lobo, J.M., Jarroca, S., Brito De Azevedo, E., Rodrigues, C., Madruga, J., Pinheiro, J., Gabriel, R., Cota Rodrigues, F. \& Pereira, A.R. 2005. Using ATLANTIS - Tierra 2.0 and GIS environmental information to predict the spatial distribution and habitat suitability of endemic species. In: Borges, P.A.V., Cunha, R., Gabriel, R., Martins, A.M.F., Silva, L. \& VIEIRA, V., Eds., A List of the Terrestrial Fauna (Mollusca and Arthropoda) and Flora (Bryophyta, Peridophyta and Spermatophyta) from the Azores. Direcção Regional de Ambiente and Universidade dos Açores, Horta, Angra do Heroísmo and Ponta Delgada, pp. 69-113.

Hortal, J., Borges, P.A.V., Jiménez-Valverde, A., Azevedo, E.B. \& Silva, L. 2010. Assessing the areas under risk of invasion within islands through potential distribution modelling: the case of Pittosporum undulatum in São Miguel, Azores. Journal for Nature Conservation 18, doi:10.1016/j.jnc.2009.11.002.

Hortal, J., Lobo, J. M. \& JimÉneZ-VAlVerde, A. 2007. Limitations of biodiversity databases: case study on seed-plant diversity in Tenerife (Canary Islands). Conservation Biology 21, 853-863.

IzQuierdo, I., Martín, J.L., Zurita, N. \& Arechavaleta, M., Eds., 2001. Lista de especies silvestres de Canarias. Lista de especies silvestres de Canarias. Consejería de Política Territorial y Medio Ambiente, Gobierno de Canarias, Santa Cruz de Tenerife.

IzQuierdo, I., Martin, J.L., Zurita, N. \& Arechavaleta, M., Eds., 2004. Lista de especies silvestres de Canarias (hongos, plantas y animales terrestres). 2nd edition, Consejería de Política Territorial y Medio Ambiente del Gobierno de Canarias.

Jiménez-Valverde, A., Diniz, F., Azevedo, E.B. \& Borges, P.A.V. 2009. Species distribution models do not account for abundance: the case of arthropods in Terceira Island. Annales Zoologici Fennici 46, 451-464.

Jiménez-VAlverde, A., Hortal, J., Lobo, J.M., Borges, P.A.V., Abreu, C., Aguiar, A.M.F., Azevedo, E. B., Boleiro, M., Fontinha, S., Jardim, R., Oliveira, P., SÉrgio, C., Serrano, A.R.M., SIM-SIM, M. \& NUNES, D. 2008. Using predictive models of species distribution to validate biodiversity data: case studies for Madeira Island. In: Borges, P.A.V., ABREU, C., Aguiar, A.M.F., Carvalho, P., Jardim, R., Melo, I., Oliveira, P., SÉrgio, C., Serrano, A.R.M. \& Vieira, P., Eds., A List of the Terrestrial Fungi, Flora and Fauna of Madeira and Selvagens Archipelagos. Direcção Regional do Ambiente da Madeira and Universidade dos Açores, Funchal and Angra do Heroísmo, pp. 27-56.

LEATHER, S.R. 2009. Institutional vertebratism threatens UK food security. Trends in Ecology and Evolution, 24, 413-414.

LOMOLINO, M.V. 2004. Conservation biogeography. In: LOMOLINO, M.V. \& HeAney, L.R., Eds., Frontiers of Biogeography: New Directions in the Geography of Nature. Sinauer Associates, Inc., Sunderland, MA, pp. 293-296.

Martín, J. L., Arechavaleta, M., Borges, P.A.V. \& Faria, B., Eds., 2008. TOP 100-As cem espécies ameaçadas prioritárias em termos de gestão na região europeia biogeográfica da Macaronésia. Consejería de Medio Ambiente y Ordenación Territorial, Gobierno de Canarias, 500 pp.

Martín, J.L., Cardoso, P., Arechavaleta, M., Borges, P.A.V., Faria, B.F., Abreu, C., Aguiar, A.F., Carvalho, J.A., Costa, A.C., Cunha, R.T., Gabriel, R., Jardim, R., Lobo, C., Martins, A.M.F., Oliveira, P., Rodrigues, P., Silva, L., TeiXeira, D., Amorim, I.R., Fernandes, F., Homem, N., Martins, B., Martins, M. \& MendonçA, E. 2010. Using taxonomically unbiased criteria to prioritize resource allocation for oceanic island species conservation. Biodiversity and Conservation 19, 1659-1682

Martins, A.M.F. (Ed.) 2009. The marine fauna and flora of the Azores. Açoreana, Suppl. 6, 225 pp.

MAY, R.M. 1988. How many species are there on Earth? Science 241, 1441-1449.

MAY, R.M. 2009. Ecological science and tomorrow's world. Philosophical Transactions of the Royal Society B 365, 41-47.

MeHTÄLÄ, J. \& VuORISALO, T. 2005. Changing value of urban biodiversity: a reply to Millar. Trends in Ecology and Evolution 21, 116-117.

Moro, L., Martin, J.L., Garrido, M.J. \& IzQuierdo, I., Eds., 2003. Lista de especies marinas de Canarias (algas, hongos, plantas y animales) 2003. Consejería de Política Territorial y Medio Ambiente del Gobierno de Canarias.

Myers, N., Mittermeler, R.A., Mittermeler, C.G., FonsecA, G.A.B. \& KENTS, J. 2000. Biodiversity hotspots for conservation priorities. Nature 403, 853-858.

ØDEGAARD, F. 2000. How many species of arthropods? Erwin's estimate revisited. Biological Journal of the Linnean Society 71, 583-597.

PARR, C.S. \& CUMmingS, M.P. 2005. Data sharing in ecology and evolution. Trends in Ecology and Evolution 20, 362-363.

REED, M.S. 2008. Stakeholder participation for environmental management: a literature review. Biological Conservation 71, 583-597.

Rozzi, R., Armesto, J.J., Goffinet, B., Buck, W., Massardo, F., Silander, J., Arroyo, M.T.K., Russell, S., Anderson, C.B., Cavieres, L.A. \& CallicotT, J.B. 2008. Changing lenses to assess biodiversity: patterns of species richness in subAntarctic plants and implications for global conservation. Frontiers in Ecology and the Environment 6, 131-137. 
Santos, A.M.C., Whittaker, R.J., Triantis, K.A., Borges, P.A.V., Jones, O.R., Quicke, D. \& Hortal, J. 2010. Are species-area relationships from entire archipelagos congruent with those of their constituent islands? Global Ecology and Biogeography 19, 527-540.

SCHAEFER, H. 2003. Chorology and diversity of the Azorean flora. Dissertationes Botanicae 374, 1-130.

SILVA, E. \& GABRIEL, R., Eds., 2009. As atitudes face ao ambiente em regiões periféricas. Fundação para a Ciência e Tecnologia \& Universidade dos Açores, Angra do Heroísmo.

Silva, L., OJedA Land, E. \& Rodríguez Luengo, J.L., Eds., 2008. Invasive Terrestrial Flora \& Fauna of Macaronesia. TOP 100 nos Açores, Madeira e Canárias. ARENA, Ponta Delgada.

Silva, L. \& SMITH, C.W. 2006. A quantitative approach to the study of non-indigenous plants: an example from the Azores Archipelago. Biodiversity and Conservation 15, 1661-1679.

Soberón, J., JimÉnez, R., Golubov, J. \& Koleff, P. 2007. Assessing completeness of biodiversity databases at different spatial scales. Ecography 30, 152-160.

Soberón, J., Llorente, J. \& Benítez, H. 1996. An international view of national biological surveys. Annals of the Missouri Botanical Garden 83, 562-573.

Soberón, J.M., Llorente, J.B. \& OÑATE, L. 2000. The use of specimen-label databases for conservation purposes: an ex- ample using Mexican Papilionid and Pierid butterflies. Biodiversity and Conservation 9, 1441-1446.

Soberón, J. \& Peterson, A.T. 2004. Biodiversity informatics: managing and applying primary biodiversity data. Philosophical Transactions of the Royal Society of London B 359 , 689-698.

SuAREZ, A.V. \& Tsutsui, N.D. 2004. The value of museum collections for research and society. Bioscience 54, 66-74.

Triantis, K.A., Borges, P.A.V., Ladle, R.J., Hortal, J., GasPAR, C., Dinis, F., MENDOnÇA, E., Silveira, L.M.A., Gabriel, R., Cardoso, P., Melo, C., Santos, A.M.C., Amorim, I.R., Ribeiro, S.P., Serrano, A.R.M., Quartau, J.A. \& Whittaker, R.J. 2010. Extinction debt on oceanic islands. Ecography 33, 285-294.

Valentini, A., Pompanon, F. \& Taberlet, P. 2009. DNA barcoding for ecologists. Trends in Ecology and Evolution 24, $110-117$.

WiLliams, P.H. 1999. WORLDMAP iv. Windows: Software and Help Document 4.1. Privately distributed, London.

WiLson, E.O. 1984. Biophilia. Harvard University Press, Cambridge, MA.

Zurita, N. \& Arechavaleta, M. 2003. Banco de datos de Biodiversidad de Canarias. Boletín de la Sociedad Entomológica Aragonesa 32, 293-294. 